\title{
Perspectives Perspectives
}

This section features: (1) reactions of readers to articles and reviews published in the Journal and the replies of authors to whom the comments are addressed (if forthcoming) and (2) viewpoints and opinions expressed in the form of a report, commentary, or interview on issues or topics of current interest.
Cette section sera consacrée à deux types d'articles:

1. La réaction des lecteurs aux articles parus dans la revue et la réponse de leurs auteurs, s'il y a lieu.

2. Les points de vue et les opinions, présentés sous forme de comptes rendus, de commentaires, de chroniques ou d'entrevues, sur des sujets d'actualité ou d'intérêt général.

\section{LEADERSHIP IN THE PUBLIC SECTOR: ESL FOR ADULTS IN BRITISH COLUMBIA 1976 - 1983}

\section{Gordon and Mary Selman}

In the period of 1976 to 1983, the Continuing Education Division of the British Columbia Ministry of Education provided vigorous and influential leadership in the public sector of adult education in the province, especially in the direction of serving more effectively certain disadvantaged groups. Prominent among these were the many persons in need of instruction in English as a second or additional language. We wish here to indicate the nature of these initiatives, the policies adopted, methodologies employed and results achieved, prior to the drastic curtailment of these efforts in the current period of fiscal restraint and shift of policy on the part of the Ministry.

\section{Historical Background}

The provision of ESL services in British Columbia has a relatively long history, considering the youth of the province. By the 1860 s early missionaries on the Coast were teaching English to Native Indians and classes for oriental immigrants were offered by the churches. In 1908, the Y.M.C.A. in Vancouver was the first organization to offer English classes to persons of any linguistic background, rather than ones aimed at a single ethnic 
group (Selman 1971). The Vancouver School Board was the pioneer public institution in this work, its classes in "English for Foreigners" being inaugurate in 1911. ESL classes were offered free of charge to unemployed persons during the Depression (Selman 1976). In 1933, the first teacher training course in this field was given at the Provincial Summer School for teachers, in Victoria. During the period of heavy immigration following World War II, there was steady growth in ESL offerings and enrollments in both the public and private sectors. In 1957-58, for instance, there were 3,400 registrations in ESL classes given by school boards in B.C (1,800 in Vancouver) and in 1965-66, the numbers reached 3,538 in the whole province (217 classes), including 2,352 (103 classes) in Vancouver. In addition, the Correspondence Branch of the Department of Education was active in this work. In its peak year of activity, 1957-58, 13,287 persons in the province were supplied with its instructional materials on ESL and Citizenship. Little in the way of teacher training was available until the University of British Columbia offered a summer course in 1966, and introduced a masters degree two years later.

A major expansion of ESL services took place in Vancouver in the early 1970s. With the creation of Vancouver Community College in 1965 and the subsequent transfer of ESL for adults to it from the school board, the impetus given the field by infusion (by means of seat purchases) from the federal Manpower program, services in Vancouver took a leap forward. Enrollment in ESL programs more than doubled from 1972 to 1975 (personal communication, P. Wakefield, 1975). Vancouver Community College became - and has remained - by far the largest provider of ESL programs in the province.

\section{The Faris Report}

A series of public inquiries were commissioned in 1975 by the Minister of Education in order to guide public policy development and to increase the outreach of educational services, both geographically and in terms of reaching the educationally disadvantaged. Of particular relevance here was the Committee on Continuing and Community Education, chaired by Dr. Ron Faris. One of the chief recommendations of the Faris Committee was that priority be given to certain "areas of special concern", of which ESL was one. Six detailed recommendations on ESL were included in the report, including: that ESL services be expanded and be made more widely available; that strong leadership for the development of the field be provided within government; that individualized instruction in this field be provided; that programs be provided as well in non-institutional settings convenient to the learner; and that the field be financed in such a way 
that "no tuition fee need be charged citizens or landed immigrants for courses that are part of a program of English as a second language" (Report 1976, p. 31; Cassidy 1982).

\section{Discussion Paper}

Pursuant to the recommendations of the Faris Report, the Continuing Education Division of the Ministry sought advice concerning its role in ESL. In the spring of 1978, the Division employed Mary Selman to prepare a report and appointed an advisory committee representative of institutions in the field to provide input and to critique the drafts of the report. Completed in 1978, the report was published in the following year under the title, Discussion Paper: English as a Second Language for Adults. It described the multi-ethnic nature of the province and the current educational provision for ESL. It included recommendations for policies, programs and practices for the Ministry itself and for the public institutions responsible for the delivery of programs.

The paper pointed out that the continuous arrival of immigrants to B.C. over the years had built up a backlog of people who for various reasons had not learned sufficient English to allow them to be fully participating members of Canadian society. Because of their limitations of language, they were barred from advancement in employment and were unable to take advantage of existing programs for job orientation, skill or academic upgrading. They were in some cases not eligible for citizenship because of their limited proficiency in the English language. Data were provided to show the unequal availability of opportunities to learn English. Seventy per cent of the provincial provision for ESL was in Vancouver, despite the fact that at least half the immigrants lived outside the city.

The report recommended that access to ESL be increased, not only by making more institutional classes available, but also by the delivery of services by other means, such as community, workplace, learning center and independent study programs. The paper stated that 75 per cent of the ESL teachers working with adults outside the lower mainland (Greater Vancouver) had no specific training in ESL. It recommended that efforts be made to improve the quality of teaching through in-service and preservice training and curriculum development. It stated that, "a core of full-time trained instructors should be provided at each institution that offers ESL programs" (Discussion Paper 1979, p. 3). It urged the development of regional resource centers which would provide for exchange and development of ESL materials and information. The paper also recommended that more adequate financing be made available and that the Ministry should employ a full-time consultant in ESL for adults. 


\section{Policy Framework and Instrumentalities}

Following the submission of the Faris Committee report, the Ministry of Education considerably upgraded the status and "visibility" of adult education in the public service by creating, in 1977, a Division of Continuing Education within the post-secondary section of the Ministry. In subsequent years, greatly increased resources were made available to the new Division, in the form of professional staff (core staff and seconded personnel) and funding for various projects and programs. These resources, in staff time and funds, judiciously managed and combined with policy initiatives, made it possible in the subsequent six years to bring about considerable growth and increased effectiveness in the adult education services of the public sector, including the field of ESL. The approaches used by the Division will be considered under six headings.

1. Consultant on ESL for Adults. Pursuant to the recommendations contained in the Faris Committee report and in the ESL Discussion Paper, the Division appointed a full time consultant for this field, who could give leadership and assistance of a specialized kind in this program area. The Consultant's activities are described in our next section.

2. Continuing Education Projects Fund. The Ministry created a new special projects fund, available to colleges, institutes and school boards for projects which were innovative in character and which were promising in terms of improving the services available to priority groups, generally the educationally disadvantaged. Approximately half the funds were assigned each year to Adult Basic Education (ABE) projects, including ESL. In a trial year (1977-78), $\$ 117,000$ was made available for use in this way and this grew to $\$ 500,000$ in subsequent years. By this means a great deal of significant outreach activity, curriculum development and innovative service delivery were made possible.

3. Policy Development. Although the public educational system of B.C. had for some decades offered a wide variety of adult education programs (with annual participation rates in most years higher than in any other province), this system had very few statements of policy. Consideration of policy questions was launched in the Faris Report and the ESL Discussion Paper and in late 1979 the Ministry embarked on a process aimed at policy development for adult education. This process included draft policy statements issued for comment by the field, redrafted in the light of the feedback, and finally issued as policy over the signature of the Deputy Minister (so it was assumed). A new Minister of Education was appointed at this stage and to everyone's astonishment, when he was asked at a public meeting about the ABE-ESL policy statement, his response was that it was not truly a government policy, but rather a statement issued by 
a Ministry official. The "policy" on ABE and ESL, because of its considerable financial implications, was taken under consideration by the Minister and by the time this process was eventually completed, fiscal "restraint" had been declared. In the spring of 1982, a watered-down version of the policy was issued, but with a covering letter indicating that even this version could not be fully implemented in those difficult times.

4. In-Service Training in Adult Education. In addition to the specific ESL training provided by the Consultant (see below), the Continuing Education Division conducted in-service development activities for administrators in the colleges and the school boards, which consistently involved efforts to sensitize these educators to the needs of disadvantaged people. In addition, manuals of practice were published concerning such areas as teaching adults, program planning and community needs analysis.

5. Special Financial Measures. In 1981, the Ministry launched ABESAP, a financial assistance plan for ABE and ESL students. The Ministry also encouraged and for a time assisted financially the Westcoast Reader, a tabloid format newspaper designed especially for ESL students, but used widely in both ESL and ABE work. The B.C. government, after twenty years delay, finally signed in 1983 the federal Textbook Agreement of 1963, under which substantial federal funds became available for the acquisition and production of teaching materials for ESL students.

6. Research and Data Collection. Of less direct benefit to practice, but of significance in the general strategy of developing the field, were the considerable efforts invested in documenting the extent and pattern of services in ESL, by means of improved statistical reports. Research on needs analysis and social indicators was sponsored in order to document the needs for ESL services in the province.

\section{The Activities of the ESL Consultant}

In keeping with the recommendations of the Discussion Paper, the Ministry appointed a Consultant in ESL for Adults. It was decided that the primary emphases for the work would be on in-service training, curriculum and program development.

In-service training activities included numerous workshops throughout the province. Colleges and school districts co-operated in planning and sponsoring these activities and the Ministry provided financial support and supplied resource people as required. The topics of the workshops were chosen on the basis of interests and problems in the various regions. Topics dealt with included: teaching techniques, cultural factors in ESL, integrating the teaching of the skills (listening, speaking, reading, writing), identifying student needs and planning objectives to meet them, teaching 
multi-level classes, using community resources in teaching ESL, and introduction to the curriculum guides. The consultant recruited teams of resource people to conduct these workshops. They came from several institutions, including Vancouver Community College, Vancouver School Board, Douglas College and the Universities of British Columbia and Simon Fraser.

In 1980 and 1981, the demand by institutions for assistance with ESL rose sharply because of the influx of refugees from Indo-China. Centers which previously had not provided ESL classes were plunged into doing so, on short notice. The Ministry sponsored a special conference in order to provide assistance to agencies with respect to the language and adjustment problems of this group. Another Ministry conference which elicited a lively response was an $\mathrm{ABE} / \mathrm{ESL}$ "Bridge" conference. It helped to identify areas of overlap between the fields and to foster co-operation among instructors for the benefit of the students.

A series of four videotapes, with supporting print materials, were developed for use in in-service training. The subjects of these tapes were: teaching multi-level classes, teaching listening and speaking, teaching pronunciation, and teaching from a functional approach. These were distributed to all colleges and school districts involved in the provision of ESL.

Two major curriculum development projects were carried out during this four year period, ESL for Adults: A Curriculum Guide (1981) and ESL for Adults: English for Work (1982). They were intended to provide the instructor with a guide to content and procedure for teaching adults. The material addressed adult needs and took into account principles of adult education. The guides benefited from the work of the Council of Europe in the area of language analysis. ESL for Adults dealt with basic language needs in six different adult roles, family member, citizen, consumer, worker, learner and community member. English for Work took the worker role, developed it further, and provided materials and guidance for the teacher of students wishing an employment orientation. Following the publication and distribution of each guide a series of workshops were held to introduce instructors to the material. When the consultant's position was terminated in 1982, the workshops were continued, organized under contract by the Vancouver School Board.

In addition to working on curriculum and professional development, the consultant served as a co-ordinator and program planning consultant. She edited a provincial ESL newsletter for two years, which was subsequently incorporated into a general newsletter of the Continuing Education Division of the Ministry. ESL materials were made available through a provincial post-secondary resource center. It concentrated on curriculum development materials and course outlines. 
In the summer of 1982, the appointment of the ESL consultant was terminated and responsiblity for further developmental work devolved upon the other personnel of the Ministry.

\section{Development of the Field 1976-1983}

In spite of the improvement in data services, it is not possible to provide a complete picture of the development of ESL services in this period, even in the public sector. The information which follows has been extracted from Ministry reports for the years indicated. These bare statistics do not reveal the rich development of the field in terms of the variety of different approaches taken, such as classes for mothers of young children, classes in outreach locations, tutoring and other one-to-one services, English for vocational and other special purposes, and other specialized forms of service.

Although much is not revealed by the general statistics, some overall trends are clear. There was a faster growth rate in the ESL programs for adults than in the continuing education programs as a whole.

In the years 1976-77 and 1977-78, the figures issued were based on Statistics Canada data and they did not contain ESL enrollments as a separate category. For the subsequent four years, enrollment figures were as follows:

Enrollments in ESL Programs - B.C.

Year

1978-79

$1979-80$

$1980-81$

1981-82
Sch. Bds.

5,840

6,629

6,313

7,712
Colleges \& $I$.

Total

3,812

4,612

6,096

15,108
9,652

11,241

12,409

22,820

NB. The sharp increase in the college figures for 1981-82 reflects the inclusion for the first time of all Vancouver Community College ESL enrolIments, most of which that college does not categorize as continuing education.

Unfortunately, official statistical reports were suspended at the time of the budget cuts in 1982-83 and parallel statistics to those above are not available for subsequent years.

A further statistic of interest is the number of student contact hours in ESL programs. 
Number of Student Contact Hours in ESL Programs - B.C.

\begin{tabular}{cccc} 
Year & Sch. Bds. & Colleges \& $I$. & \multicolumn{1}{c}{ Total } \\
$1978-79$ & 359,563 & 194,013 & 553,576 \\
$1979-80$ & 562,238 & 395,902 & 958,140 \\
$1980-81$ & 386,173 & 502,403 & 888,576 \\
$1981-82$ & 520,895 & 941,175 & $1,462,070$
\end{tabular}

NB. See note above re college figures in 1981-82

This second set of figures reveals even more clearly the increasing role of the colleges as providers of ESL instruction.

It is important to note that in the year 1981-82, when overall enrollments in continuing education in the provincial institutions was down marginally $(0.3 \%$ ), enrollments in ESL programs (and ABE) showed a very considerable increase, presumably at least in part a result of the priority which was being attached to these two areas by the Continuing Education Division of the Ministry.

\section{Other Forces}

While the focus of this report is largely on the role of the Ministry of Education in providing leadership in ESL for adults, it is important to recognize that during the period under discussion, several other institutions and organizations contributed substantially to the improvement of services in this field.

All of the fifteen colleges and eight of the school districts provided ESL courses for adults. The program at King Edward Campus of Vancouver Community College, which was larger than all the rest put together, developed a wide range of programs on site and in the community. It also produced a number of useful ESL publications. Douglas College sponsored a number of in-service development workshops for ESL teachers in the Lower Mainland of the province.

The activities of the professional body, Teachers of English as an Additional Language (TEAL) are wide ranging and are generally aimed at strengthening and improving practice and policies in the field. TEAL also supports particular projects in ESL such as the Westcoast Reader and holds an annual conference and professional development workshops. It provides scholarships for teachers who want to pursue further formal education and subsidizes travel to conferences for members who are making presentations.

"Directions ESL" is an organization jointly sponsored by TEAL and the multicultural organizations: SUCCESS (which works on behalf of oriental immigrants), the Immigrant Services Society, and by the Britan- 
nia Community Services Centre. Its goal is to improve policy for the provision of ESL programs for both children and adults. It has pressed government to improve its services to various groups in need of more adequate ESL provision. It can take much of the credit for precipitating the signing of the federal Textbook Agreement in 1983, a long overdue action on the part of the province. This organization is currently being succeeded by "ESL Forum".

TEAL has also represented B.C. on the TESL Canada Board. It has representation on the Board of the Pacific Association for Continuing Education and is also an affiliate of the B.C. Teachers Federation and TESOL, the American-based international organization.

The three universities in the province, through their teacher training programs and their involvement in professional organizations, have had an important impact on ESL in the province. Professors at all institutions have given outstanding service through publications, organizing, leadership in the professional organization and teaching prospective ESL teachers.

\section{ESL A Ministry Priority}

The main objective of the Continuing Education Division in the period 1976 to 1983 was to promote more effective education for the disadvantaged, including those in need of instruction in ESL. These efforts were made possible in part by the political leadership who sought general improvement in educational services, and Dr. Faris, who was committed to the leadership role of government in promoting social justice and equity, through education. Faris utilized the resources available to him, including his professional team, policy initiatives, research, in-service training and the strategic use of available funds, in order to improve and expand the services of the public educational institutions of the province to all adult learners, but especially to the most educationally disadvantaged. Much was accomplished, but fiscal restraint and a shift of Ministry policy have dealt these efforts a severe blow in recent years.

\section{Restraint and Policy Shift - 1983}

Beginning in 1982, the Government of British Columbia, in response to its falling income, instituted a policy of fiscal restraint. Following its resounding electoral victory in May of 1983, the Bennett Government accelerated the restraint policy and announced its intention to reduce the size of the civil service and reduce the functions performed by the public sector.

The impact of these policy shifts on continuing education has been profound. Government grants to school boards and college in support of 
adult education have been sharply reduced. The Special Projects Fund, which had supported considerable innovation and improvement of ESL activity, has been eliminated, as have other discretionary financial resources. All seconded professional staff positions, including the Consultant for ESL, have been terminated. In fact the Division of Continuing Education itself has been downgraded to a Branch within the Ministry and almost all its professional staff redeployed. What has clearly resulted from all this de facto, was subsequently announced as policy; that the Ministry wished to de-emphasize its leadership role in adult education, including its efforts in ESL for adults.

It is clearly the end of an era. The strong and socially useful leadership which the Ministry gave in the period 1976 to 1983 to education for the educationally disadvantaged, including those in need of ESL, has been deliberately terminated. Many programs continue, of course, but now at the discretion of the individual institutions in the system.

\section{REFERENCES}

Cassidy, F. (1982). Continuing Education Policy in British Columbia 1976-1980, Occasional Paper No. 8, Pacific Association for Continuing Education.

Discussion Paper: English as a Second Language for Adults, (1979). Victoria, Ministry of Education.

English as a Second Language for Adults: A Curriculum Guide (1981). Victoria, Ministry of Education.

English as a Second Language for Adults: English for Work (1982). Victoria, Ministry of Education.

Public School Reports, British Columbia. selected years.

Report (1976). Committee on Continuing and Community Education in British Columbia, Victoria, Ministry of Education.

Selman, G.R. (1971). Some aspects of the history of adult education in British Columbia before 1914: a preliminary survey. Unpublished manuscript, typescript, 276 pp.

(1975). Adult Education in Vancouver before 1914, Occasional Papers in Continuing Education, No. 9. U.B.C. Centre for Continuing Education.

(1976). Adult Education in British Columbia During the Depression, Occasional Papers in Continuing Education, No. 12. U.B.C. Centre for Continuing Education.

\section{THE AUTHORS}

Mary Selman is a consultant in the field of ESL for adults, and formerly Consultant, ESL for Adults, Continuing Education Division, B.C. Ministry of Education.

Gordon Selman is Associate Professor, Adult Education, Faculty of Education, University of British Columbia. He specializes in the history of adult education in Canada and B.C. 